less than 6,000 years. Such experiments must be mainly tentative, and the increased rainfall for the last few years shows that my estimate of $27 \frac{1}{2}$ inches of average rainfall was scarcely high enough. Still it may be confidently asserted that the result of the calculations is not far from the mark, and it may be inferred, that for every foot removed from the surface of the table-land, $2 \mathrm{ft}$ at least are removed from the sides and bottoms of the valleys.

NOTES ON CLASSIFICATIONS OF CYCLOSTOMATOUS POLYZOA: OLD AND NEW. BY GEORGE ROBERT VINE.

From the time of Lamouroux and Goldfuss to the present, the group of organisms which we now characterise as Bryozoa, or Polyzoa, have received marked attention from naturalists. There has been, however, many misconceptions as to the true affinities of this, with other groups,--and many misunderstandings in consequence--but at the present time Polyzoa literature is becoming rather abundant, and the misconc eptions are, to a large extent, things of the past.

With regard to this preliminary paper, I may be allowed to say that my object in writing it, is to place before the student the aims and outcome of the various classifications of the Cyclostomata extant, not for any desire of contesting the conclusions of the authors referred to, but more for the purpose of keeping controversal matter out of my future papers.

The divisions of the Polyzoa now generally recognised by naturalists :--

$$
\begin{aligned}
& \text { I.--Cheilostomata. } \\
& \text { II.-Cyclostomata ; and } \\
& \text { III.-Ctenostomata ; }
\end{aligned}
$$

were originated by Mr. Busk in his catalogue* of the Marine Polyzoa in the British Museum, and in the monograph of the Fossil Polyzoa of the Crag. $\dagger$ After the publication of the latter work, two elaborate papers followed from the pen of Professor Smitt, on Scandinavian

* Parts I. and II. † $\quad$ 1859. 
VINE: CLASSIFICATIONS OF CYCLOSTOMATOUS POLYZOA.

Bryozoa, ${ }^{*}$ who accepted the divisions, but not the synoptical arrangement of Busk. Professor Smitt, however, based his modified arrangement of the Cyclostomata, on apparently more solid ground than that of Mr. Busk, bnt many of his generic divisons were suggestive, rather than natural. Mr. Busk says: "Although unprepared to follow Professor Smitt in many of his conclusions, and disposed to disagree with him in many points as regards the limitation of genera and species, the Author is fully convinced that Professor Smitt's observations will mark the commencement of a new era in the study of the Polyzoa, and that they will serve, in many cases, to indicate the direction in which our attempts at their natural classification should proceed." $\dagger$

In his introductory chapter, $\ddagger$ Mr. Hineks says, respecting Professor Smitt's labours, that "he has aimed at a geneological classification, starting with the proposition that the variations of species follow the line of their development, and may be in a great measure explained by it. The Polyzoa .... as compound animals offer great facilities for the study of the laws, and causes of variation. The differentiation of the colony gives us a series of variations, rumning from the early and simple states, to the fully developed form, which is the parallel of the series of differences amongst species." As an example of Smitt's meaning, Mr. Hincks cites an appropriate example.|| "Thus, the British species of Crissia represents the evolutional stages of one and the same type, of which Smitt regards $O$. geniculatx, Milne-Edwards, as the first and simplest." There is no doubt, whatever, but that Professor Smitt's classification of Recent Polyzoa rests on a thoroughness of research, as suggested by Mr. Hincks, "and the important contribution which he has made towards a natural system," it is impossible to estimate too highly, "however much we may be disposed to dissent from some of his results." Mr. Hincks further remarks,--1 "In his great work on the Embryology of the Polyzoa, Barrois contends that in classifying

* British Fort. Ofver Scand. Hafs. Bryoz. 1864-5.

$\dagger$ Catalg. Cyclostomatous Polyzoa (Busk), 1875, p. 1.

‡ British Marine Polyzoa, p. exx., 1880. ॥ Ibid.

\$ Brit. Mar. Polyzoa, p. exxiii. 1 Ibid. 
these animals, account should be taken of all the forms in the lifeseries together, and sketches an arrangement suggested by the study of the larvo (p. 250), for comparison with that of Smitt, from which it differs in some respects."

One of the real difficulties which the systematist has toencounter in dealing with Fossil forms, is shown by Mr. A. W. Waters, in his paper on the "Fossil Cyclostomatous Bryozoa, of Australia.* The author says: "The determination of the Cyclostomata presents much greater difficulties, and is much more unsatisfactory than that. of the Cheilostomata, as there are fewer characters that can be used." In classifying the 'Tertiay Cyclostomatous Bryozoa, of Australia, Mr. Waters endeavoured to free himself, to some extent, from the modes of other authors in dealing with the group, and in doing so, he presents to the student new lines of investigation. The size of the aperture, as pointed out by Snitt, and re-worked by Mr. Waters, "seems to be fairly constant in the same species. The variation in size is not very great, ranging only from 0.03 millim. to 0.2 millim., in all species measured; but anything greater than 0.16 millim., or less than 0.07 millim., is very exceptional," (p. 675.) One of the more useful characters in the Cyclostomata for determining specific-and perhaps even generic variation -is found in the calcareous closure, + which may be noticed in some of this Zocecia of Recent, Tertiary, and even Cretaceous Polyzoa. "The position of these closures, together with the nature of the perforations, is a character of considerable importance," although it is neither so available nor so important as the horny operculum," of the Chilostomata (Q. J. G. Soc. Vol. xl., p. 675.)

After touching upon these purely structural features of the Cyclostomata, Mr. Waters offers many suggestions as to the arrangements of the group, and on this head he does not differ very materially from that of Mr. Busk and Mr. Hincks, except that in discussing the merits of some of the genera accepted by Reuss and others, he questions their value. These will be referred to again further on.

* Quart. Journ, Gəol. Sos. Vol. xl., p. 674.

$\dagger$ Closure of the Cyclos. Bryczoa. Jour. linn. Soc. Vol. xvii, p, 400. 
In his last work,* Mr. Busk, in arranging the Cyclostomata, of the Challenger dredgings followed that, which he had previously adopted in his Monograph of the Crag Polyzoa, 1857, and in the British Museum Catalogue, Pt. III., 1875, "the number of species procured by H.M.S. Challenger, belonging to this sub-order, not having been sufficiently large to lead to any material change in it." In dealing with the Geological distribution of the sub-order, Mr. Busk does me the honour of quoting and accepting my opinions on two very important points. "To the sub-order Cyclostomata, belong most of the oldest Fossil Polyzoa that have been found up to this time, whilst' as yet we have no clear evidence that Cheilostomatous types existed in Palæozoic times :' (Vine, Quart. Jour. Geol. Soc. Vol. xl., p. 332.) Although in the Mesozoic and Tertiary strata Fossil Cheilostomata are numerous. The palæontological evidence as to the antiquity of the Cyclostomata is fully confirmed and strengthened by the embryological researches that have recently been so carefully and accurately made by varions authors : for instance, M. Barrois (Ann Mag. Nat. Hist., ser. 15. Vol. x., p. 391, footnote) says that the study of the structure of the larva, and of the formation of the cell coincides with palæontology in furnishing us with perfectly concordant results, which are conclusive as to the antiquity of the Cyclostomata." $\dagger$

In his latest Palæontological papar, Mr. A. W. Watersł remarks, suggestively, as follows:- "I would propose that we should divide the Cyclostomata into two sub-divisions, namely-first, the Partllelata; and secondly, the Rectrungulata. 'This would simplify the arrangement of the larger groups, and so far we gain by Mr. Waters' suggestion. 'The lesser groups, however, are left nominally the same, as arranged by Busk and Smitt, and by the Rev. Thomas Hincks.

To a large extent, Mr. Waters has been engaged in the study of species and groups of Cyclostomata, found in the Upper Tertiary Rocks of Australia, as well as the more recent forms. The evidence afforded by the study of these is necessarily limited, but in every

* Report on the Polyzoa (Cballenger Rep.), Second Part Cyclostomata, 1883, p. ii. $\dagger$ Ibid, pp. iii. and iv.

$\$$ Quart. Journ. Geol, Soc. Aug, 1887. Vol. 42 p. 337 . 
case where it was possible for him to do so, reference has been made to species of fossils found in the Cretaceous, and also in the Jurassic rocks, in the neighbourhood of Caen; and the celebrated Mrstricht beds, so ably illustrated by the labours of Lamouroux, Goldfuss, Haime, D'Orbigny and Hagenow. Since then, however, many of the beds of the horizons named have been reworked by Dr. Pergens and A. Meunier, and the whole of D'Orbigny's species have been critically examined by Dr. Pergens, and I have not the least doubt, but that many suggestions will be forthcoming, when he arranges his notes for publication. As it is, I can only deal with published papers, and in several of these I find certain conclusions arrived at by the author in his critical studies, which will have to be considered before a final arrangement of the Cyclostomata can be made. Thus, in their joint paper on "New Bryozoa of the Upper Cretaceous,"* (or Mastricht Beds), the authors establish a new family, and three new genera, for the reception of a peculiar group of Polyzoa; and in other papers several of the almost obselete genera, of D'Orbigny, have been consistently revived. The new Family, Cameraporids, the authors place in the "Centrifuginés de D'Orbigny, division des Tubulinés," and the new Genera, are called respectively Cumerapora (one species); Clausacamerapora (one species and variety); and Curvacamerapora, also one species.

From all this it may be gleaned that although much has been done by the authors who have succeeded Busk and Smitt, much still remains to be done, even with the proper classification of the Mesozoic Cyclostomata, let alone the Palæozoic groups, which are now being so elaborately illustrated by Mr. E. O. Ulrich, Palæontolog ist of one of the United States Geological Surveys.

All that I shall attempt, then in this paper, is to place before the student of our Fossil Polyzor, the classification of the Cyclostomato adopted by the several authors already mentioned, so that he may be able to judge of their relative, or suggestive value.

The classification of the Jurassic Bryozoa, by Jules Haime,;" is a very simple affair : all his species-excepting two-are placed in

\footnotetext{
* Memories de la Soc. Roy. Malacologeque de Belgique Tome xx., 1885.
} † Jarassic Bryozoa, 1854. 
one family, Tubuliporina, M. Edwards. Haime, however, did not endeavour to give a synoptical arrangement of his groups, and it was not until the appearance of Mr. George Busk's Monograph of the Fossil Polyzoa of the Crag,; that any really detailed notice of the fossil groups were published, and then Mr. Busk confined his notice more particularly to Recent and Tertiary Polyzoa. It may be well to remember that the Crag Monograph was "originally undertaken by the late much-lamented M. Jules Haimes, but he was unable even to commence it, before death put an end to the labours of one whose accurate knowledge and practised observation of similar fossil remains, would have enabled him to treat the present subject far more satisfactorily than it has been in my power to do." $\uparrow$ Whether Haime, as Mr. Busk suggests, would, or would not have given to the world a better monograph of the Crag Polyzoa, is useless to speculate about; but no doubt, Haine's familiarity with the Jurassic forms, would have helped him much in the nomenclature of speciesespecially so, as Mr. Busk admits that he had "formed but an imperfect idea of the difficulties attending the investigation and accurate discrimination of fossil forms," previous to his labours on the Crag species. To this we may owe some of the hesitations on the part of Mr. Busk, and in all probability he overlooked the structural peculiarities of many of the earlier fossils; and to some extent he may have misinterpreted the structural features of others. On the whole, however, the synopsis of the Tubulipurina of M. Edwards has been well divided by Mr. Busk; and generally speaking, his Sub-orders have been accepted by leading authorities who have made a comparative study of Fossil Polyzoa. It would be beside my purpose to refer to, or criticise the divisions of Hagenow and Reuss, because it must be admitted that their arrangements, previous to the publication of the Crag Polyzoa were very artificial, and in his later works, Reuss followed Busk in his arrangements.

In his introductory observations, Mr. Busk gives the synopsis of the Primary Divisions of the Polyzoa, as followed by him, partly

* 1850 .

† Busk Advert. to crag Polyzoa.

Since found Recent Catalogue of Cyclos-Busk, p. 29, 1875. 
in his two British Museum Catalogues, but the plan of the synopsis generally, we owe to Professor Allman :*-

Order 1.-Phylactolemata Allman.

With two Sub-orders.

" II.-Gymnolemata Allman.

Sub-order III.-Paludicellea (fresh water).

" IV.-Cheilostomata, Bush (Marine).

", V.-Cyclostomata, Bu.k (Marine).

" VI.-Ctenostomata, Busk (Marine).

Only Sub-order V. will be dealt with in this paper, and following Mr. Busk, $\uparrow$ I will italicise, as he has done the families and genera, which contain living species:-

I.-Articulatæ s. radicatre

I. Crisiid

1. Crisia.

2. Crisidea.

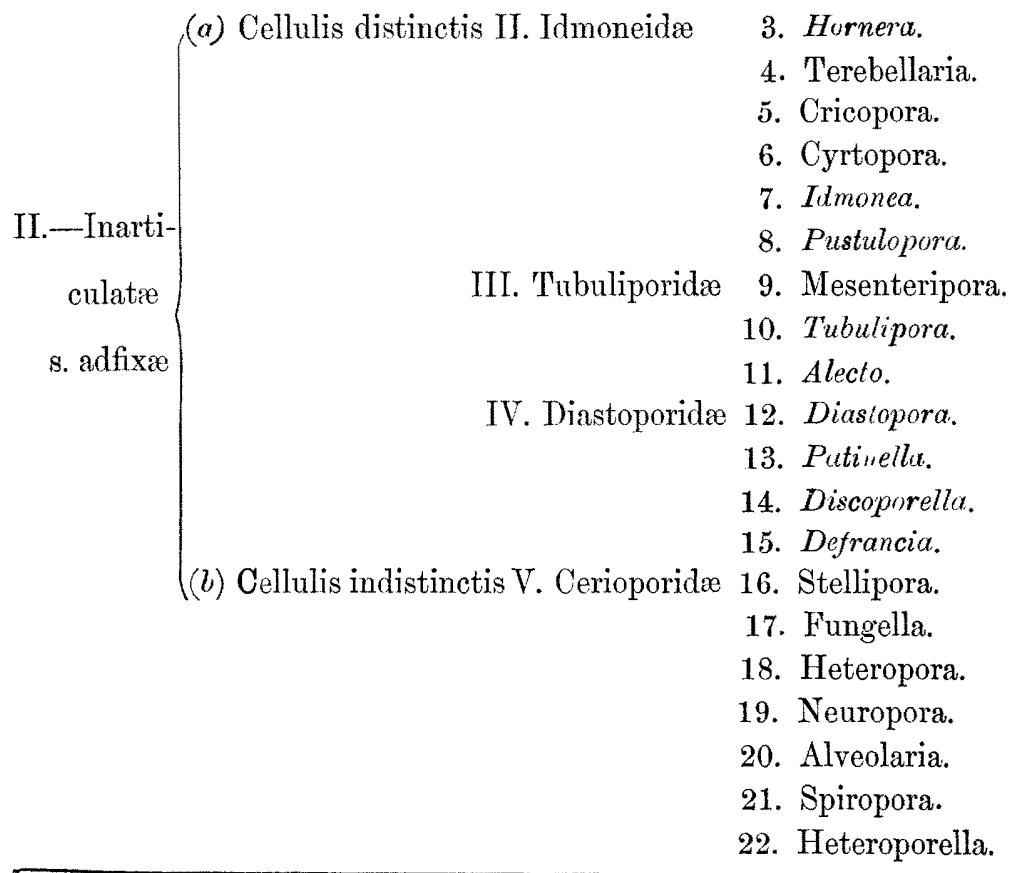

* Crag Polızoa, pp. 8-9.

† Ibid, p. 91. 
VINE: CLASSIFICATIONS OF CYCLOSTOMATOUS POLYZOA.

VI. Theonoida 23. Theonoa.

24. Fascicularia.

25. Lopholepis.

26. Apsendesia.

VII. Frondiporidx 27. Frondipora.

28. Truncatula.

29. Distichopora.

30. Plethopora.

It is of no service whatever, to hide from the student the suggestion that the above grouping is anything but natural, when fossil species below the Crag are under consideration, or even certain species in the Crag. To a large extent the grouping is built up from partially facial characters, and I am not at all surprised to find Palrentologists offering suggestions, or making re-arrangements of the family grouping. 'The family Cerioporide is particularly obnoxious, for there is not the least affinity between the Spiropora of Haime, and the Heteroporell, of Busk. The type of the family Idmoneidæ should have been, so far as I am able to judge, Ilmones, and not Hornera; then the genus Terehellaria, as defined by Lamouroux and D'Orbigny, would find no resting-place here. If, however, we accept the genus as defined, and in all probability limited, by Haime, Terebellaria is a Diastopora adhering to, and simulating the undulations or ramifications of the fossil organism to which it is attached. Cricopora and Spiroporu, in all probability, belong to the same group, yet one genus is placed in the Idmoneidx, and the other in the Cerioporidæ-one, the cells distinct; the other, the cells indistinct.

Professor Smitt's arrangement of the Cyclostomata, ${ }^{*}$-as already stated-is open to objections, but his grouping is by far the more natural ; and it must not be forgotten that Smitt treated of recent Cyclostomata only, whereas Busk endeavoured to grapple with recent and fossil species in one synopsis. Smitt arranged the Cyclostomata as follows :-

Tribe, Infundibulata, Gervais.

Order, Cyclostomata, Busk.

* Krit. Fortneck. Ofver Skandinaviens Hafs Bryozoer, 1864-65. 
$=$ Centrifuginea, D’Orbigny.

Sub-order, Radicellata, D’Orbigny.

$$
\begin{array}{ll}
\multicolumn{4}{c}{=\text { Articulata, Busk. }} \\
\text { I.-Family Crisia. } & \text { 1. Crisia, Lamx. }
\end{array}
$$

Sub-order, Incrustatatx, D'Orbigny.

= Inarticulata, Busk.

I. 'Tubulinea, D'Orbigny.

$$
\text { II.-Family Diastoporide. 2. Diastopora, Lamx. }
$$

III.--Family Tubuliporidæ.

3. Mesenteripora, M. Edw.

$$
\begin{aligned}
& \text { Sub-genus-4. Idmonea, Lamx. } \\
& \text { Sub-genus--5. Phalangella, Gray. } \\
& \text { Sub-genus-6. Proboscina, Aud. } \\
& \text { IV.-Family Horneridæ. 7. Hornera, Lamx. } \\
& \text { V.--Family Lichenoporidæ. 8. Discoporella, Gray. } \\
& \text { II. Fasciculinea, D'Orbigny. } \\
& \text { VI_-Family Frondiporidæ. 9. Frondipora, Blainville. } \\
& \text { VII.-Family Corymboporide. 10. Corymbopora, Mich. } \\
& \text { 11. Defrancia, Bronn. }
\end{aligned}
$$

As already stated, Mr. Busk, in the third part of the British Museum Catalogue, agreed with Professor Smitt in his critical suggestions, but he failed to modify, to any great extent, the synoptical arrangement of the Cyclostomata, as adopted for the Crag Monograph. Very wisely, the Frmily of the Diastoporidx is broken up, and limited to two Genera-Dirstopora and Mesenteripora-and another family founded for the reception of a peculiar group of Polyzoa, which occur both Recent and Fossil. The name of the typical genus, Discoporella, is the type of the Family Discoporellidæ, and the included genera are-

$$
\begin{aligned}
& \text { Discoporella, Gray. } \\
& \text { Radiopora, D'Orbigny. } \\
& \text { Domopora, D'Orbigny ; and } \\
& \text { Defrancia, D'Orbigny. }
\end{aligned}
$$

And the Frondiporidæ of the Crag, is changed to the Fasciculinæ of the British Museum Catalogue. As a matter of course, the Families 
VINE: CLASSIFICATIONS OF CYCLOSTOMATOUS POLYZOA.

Cerioporidæ and Theonoidæ are done away with, as no species belonging to these Fossil Groups are known to exist.

In the introduction* to the British Marine Polyzoa, Mr. Hincks modifies the arrangement of Mr. Busk, but on account of the limited range of the British region, some few alterations in the generic divisions had to be made when dealing with the Cyclostomata of Foreign regions. For the British Marine Polyzoa, only four families were adopted:-
I.-Crisidæ.
III.--Horneridæ ; and
II.--Tubuliporidæ.
IV.-Lichenoporidæ.

In the Catalogue of Marine Polyzoa of Victoria, $\uparrow$ Mr. P. H. MacGillivray, however, accepts Mr. Busk's family arrangements, slightly altered, but he adds several new Genera as follows :- $\ddagger$

$\begin{array}{cll}\text { Family } & \text { I.-Crisidæ. } & \text { Crisia, Lamx. } \\ , & \text { II.-Idmoneidæ. } & \text { Idmonea, Lamx. } \\ & & \text { Hornera, Lamx. } \\ \text { " III.-Tubuliporidæ. } & \text { Tubulipora, Lamx. } \\ & & \text { Stomatopora, Bronn. } \\ & \text { Diastopora, Johnston. } \\ & \text { Liripora, MacGillivray. } \\ & & \text { Entalophora, Lamx. } \\ & & \text { Lichenopora, Defrance. } \\ & \text { IV.-Discoporellidæ. } & \text { Densipora, MacGillivray. } \\ & & \text { Favosipora, MacGillivray. } \\ & & \text { Flosculipora, MacGillivray. } \\ & & \text { Vasciculipora, D'Orbigny. }\end{array}$

It will be noticed in common with other workers, that $\mathrm{Mr}$. MacGillivray uses the Generic term Entalophora, instead of Pastulopora (Busk, Brit. Mus. Cat., pt. III.) The reason which Mr. Hincks gives for reinstating the first generic name, is, on the whole, perfectly agreeable, but out of common fairness, Mr. Busk's reason for rejecting the term will be given further on. "A question arises," says Mr.

\footnotetext{
* London: John Van Voorst, 1830, p. cxxxix. † Transactions (?) Roy. Soc. Vict., 1886.)

$\ddagger$ New Genera in Italice.
} 
VINE: CLASSIFICATIONS OF CYCLOSTOMATOUS POLYZOA.

Hincks," "as to the name of this Genus (Entalophora), . . Busk seems to admit that in strict propriety, Lamouroux's designation is entitled to precedence; but he thinks that, to restore it under the circumstances, would savour of pedantry (Crag Polyzoa, p 107). I confess it seems to me that the fewer departures from the established rule the better. The accidental prevalence of a much later name, does not appear to be a reason for retaining it. On the contrary, it may be a salutary vindication of the authority of the law to reject it after such usurpation. The best cure for the disorders of our nomenclature seems to be a vigorous application of the principles which are generally accepted for its government. Lımouroux's $\dagger$ genus is characterised in a well known work; and both diagnosis and figure are sufficient for identification : its claim seems to be complete."

If the acceptance or rejection of a generic term was only a question of priority, as Mr. Hincks seems to think, then, the matter would be very easily settled, as the term Entalophora is by far the oldest one. But in this case we have two eminent authorities contending, not merely about a name, but really about a structural peculiarity which leads Mr. Busk to question the identity of Lamouroux's species as of sufficient authority to justify the acceptance of the typical form to which Lamouroux gave the name Entalophora. In his last work, Mr. Busk discussed the whole question under the generic term, Pustulopora.f The author says, "Although most recent writers, including such high authorities as Professor Smitt and Mr. Hincks, have adopted the name Entalopleora, for the genus here intended, I am inclined, with the greatest deference, to prefer M. de Blainville's and M. Milne-Edwards' name, for the reason that the species named Entalophora, by Lamouroux, appears to me to differ in at least one most important respect, it may be said from all the other known Cyclostomata, and most certainly from all with which I am acquainted, either recent or fossil, viz., in the appendages, as he terms them, leing trumpet shcuped, or gradually increasing in diameter as they increase in length. Whether this arises from an

* Brit. Miar. Polyzoa, Vol. i., p. 455. $\dagger$ Italies Mine.

‡ Challenger Report, Pt. ii., Cyclostomata, \&c., p. 18. $\$$ Italics mine, in all instances, in the body of the quotations. 
error of observation on the part of Lamouroux, or of his draughtsman, or is the true condition, may, perhaps, admit of doubt: with the exception of M. Michelin (Iconog. Pl. lvi., fig. 4), whose figure very strongly resembles that of Lamouroux, no one seems to have recorded any other form with trumpet-shaped tubes; and as even his figure does not represent them as having that form, I am much inclined to assume that Lamouroux's specimen is unique in that respect, and if correctly figured and described, that it must, on that account alone, be referred to a distinct generic type from all other known Pustuloporidæ, and in fact, as above observed, from all other Cyclostomata. (May it not be a coralline?) On the other hand, M. de Blainville's definition of Pastulopora, as distinguished from Lamouroux's Entalophora, is so clear and precise, and his genus has met with the acceptance of M. Milne-Edwards, Hagenow, Reuss, and numerous others, and in fact may be said, until quite recently, to have been in full possession of the field, that I feel no hesitation in retaining it for all forms with cylindrical tubes of the same diameter throughout; and relegating those forms, if there really be any, with trumpet-shaped tubes, to at least a distinct genus."

If we revert now to the Crag Polyzoa, p. 107, we shall find that the opinion now so forcibly put by Mr. Busk (Challenger Rep., pt. ii., as abovel, was only hesitatingly adopted in the former work. It was not then wholly a question of structure; but, as Mr. Hincks says suggestively, a question of diffidence as to priority, or clearer definition. Mr. Busk says : "I have adopted Blainville's name for this genus (Genus 3. Pustulopora), more for the reason that it has come into general acceptation, especially since its accurate definition by Milne-Edwards, than because I am satisfied it should have precedence of Entalophora, a term under which it appears quite clear that Lamouroux had intended to include similar forms. The prior appellation, however, having fallen into abeyance, except by M. D'Orbigny, whose genus Entalophora, moreover, is not confined to Cyclostornatous forms only, it seemed unadvisable, merely for the sake of somewhat pedantic propriety here to revive it."

Neither of these authors has drawn attention to the fact that Jules Haime, in his Jurassic Bryozoa, only places one species in the 
genus Entalophora, while he uses the term Spiropora for several species which would, under the restored nomenclature of Hincks, be placed under Entalophora.

In their joint memoir on the "Bryozoa of Faxæ Limestone,"** Denmark, the authors, Drs. Pergens and A. Meunier have formulated an entirely new arrangement of the Cyclostomata, so as to meet the necessities of grouping species having certain structural affinities, which, though not apparent in the more recent forms, are very abundant in the whole of the Mesozoic Rocks. So far the authors are to be commended, but unless their grouping is studied in connection with the species grooped together, the student will miss many of the finer points brought out by the authors in the arrangement. It is here, and in the Palæozoie Rocks, that we begin to lose the peculiarities on which the classsification of the more recent Cyclostomata are based; and even in his own labours on the Upper Tertiary species of Anstralia, presently to be referred to, Mr. Waters has felt the necessity of re-introducing obsolete generd. The necessity is increased whenever we deal with the Polyzoa critically, as we go backward in time. Dr. Pergens and A. Meunier, arranges the Cyclostomata as follows :-

\section{Bryozon, Cyclostomata.}

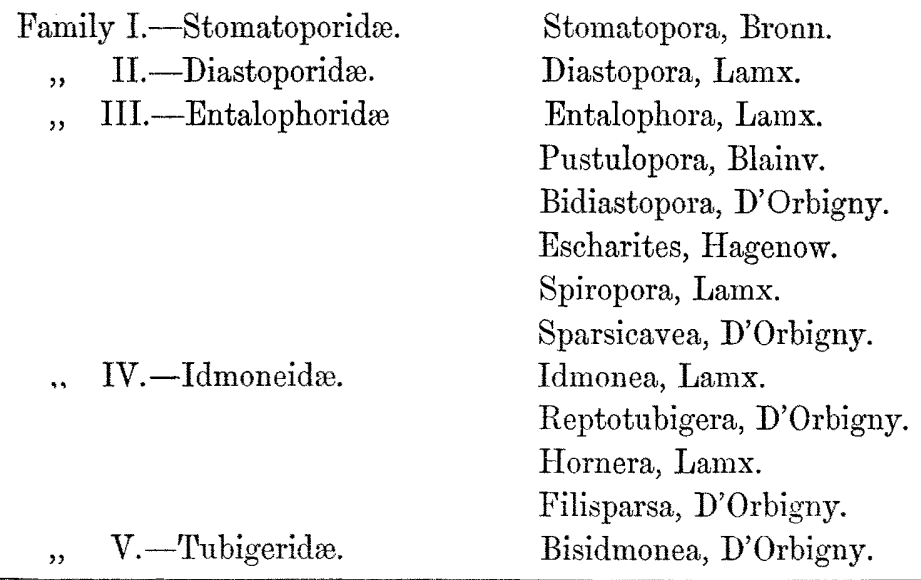

* La Faunæ des Bryozoaires Garumniens de Faxæ. Annals de la Soc. Ror. Malacol de Belgeque. Tome xxi., 1886. 
VINE: CLASSIFICATIONS OF CYCLOSTOMATOUS POLYZOA.

Tuberculipora, New genus.

"VI.-Cameraporidæ, N. Fam. Camerapora

Clausacamerapora ",

, VII.--Fasciporidæ. Fungella.

Supercytis, D’orbigny.

„, VIII.-Fasciculiporidx. Cyrtopora.

'Truncatula.

" IX.-Heteroporidæ. Heteropora.

" X-Iichenoporida. Lichenopora.

Discoporella.

Radiopora.

I have arranged the family grouping with its included genera as above, only to the extent of the published details of these respected authors. It is fair to state, however, that Messrs. Pergens \& D. Meunier are still carrying on their investigations, and how far they may modify, or restrict their grouping in future labours, I am not in a position to judge. 'The authors are in earnest with their work, and I believe we shall have some good papers from them on Faxæ Limestone, and other forms.

In his latest Palæontological Paper* on Tertiary Cyclostomata from New Zealand, Mr. A W. Waters has given us the result of his more matured views respecting the divisions of this Sub-order, and we may regard this as a supplement to his previous paper on the Cyclostomata from Australia. $\dagger$ I know full well that the attention of Mr. Waters has been directed to the grouping of the Cyclostomata for many years, and we may, therefore, regard this paper as the outcome of many years of thought. As Mr. Waters says (Op. c. p. 337), "The second part of Mr. Busk's Report is a great disappointment .... as only thirty-three species are recorded, and these are for the most part well known and common. In fact, the results of this great expedition do not seem, so far as the Cyclostomata are concerned, to exceed what I presume a specialist might, after a storm,

* Quart. Jour. Geol. Soc., Aug. 1887, pp. 337-350. $\dagger$ Q.J. G. Soc., Vol. 40, 1884, pp. 674-696. 
collect in a few morning walks in the neighbourhood of Sidney Harbour."

With regard to the classification of the Cyclostomata, Mr. Waters says (p. 337): "I would propose that we should divide the Cyclostomata into two sub-divisions, namely-first, the PARALLELATA, or those in which the surface of the Zoarium is, to a considerable extent, formed of the lateral walls of the Zoocia;" TyPES-Crisia, Entalophora, Diastopora and Tubulipora: "And secondly, the ReCrangulata, or those in which the Zooecia or cancelli open for the most part at right angles to the axis or surface of the Zoarium or sub-colony."-Types, Heteropora, Lichenopora, \&c.

There are several structural peculiarities of Cyclostomatous species pointed out by Mr. Waters in this important paper, especially "rays" or "hair-like teeth" in the Zoccia, and the closure of the tubes, as already referred to. In all our future Palæontological researches it may be well to consider the minutæ referred to, and others may be present, though overlooked by authors. I have already pointed out and described* a very peculiar mode of "closure" in a species of Entalophora from the Neocomian Clay of Lincolnshire. The arrangement of the Zoocia, the punctures of the surface, and the closures in the throat of the tubes, are similar to the figured example of Entalophora Wanganuiensis Waters. $\uparrow$ Other Mesozoic examples may be forthcoming, if a careful study of the Zoceia is made.

It will be unwise to anticipate the future work of Mr. Waters on this Sub-order, but it may be well to direct attention to the already tabulated lists of species described, and also the order in which the genera are arranged by him.

$$
\begin{array}{ll}
\text { I.-Parallelata, Waters. } & \text { Idmonea. } \\
& \text { Entalophora. } \\
& \text { Cinctipora. } \\
\text { Hornera. } \\
\text { Stomatopora. } \\
\text { Diastopora. }
\end{array}
$$

* Notes on a species of Entalophora, from the Neocomian Clay of Lincolnshire. Ann. Mag., Wat. History, Jan. 1887.

† Q. J. G. S., Aug. 1887, p. 340, pl. xviii., f. 1. 
VINE: CLASSIFICATIONS OF CYCLOSTOMATOUS POLYZOA.

$\begin{array}{ll} & \text { Tubulipora. } \\ & \text { Fascicularia. } \\ \text { Supercytis. } \\ \text { Lichenopora. } \\ \text { Reptocavea. } \\ \text { Heteropora. } \\ \text { Crisina. } \\ \text { Crassohornera. }\end{array}$

As the present papers will form the beginning of a series on Jurassic Polyzoa-both British and Foreign-I can only feebly indicate the line of inquiry that $I$ shall ocecupy in my descriptions. In the first place it may be well to notice, that the only Jurassic Monograph which we have for reference is that of Haime, which was published in the Memoirs of the Geological Society of France in 1854. In this work the author described Caen and Ranville examples as well as British, and in many cases the British examples fell under the head of a type described from a foreign source. There was no objection to this, but it frequently happens that the British example differs in some few particulars - which will be referred to in the course of descriptions - and these minute differences are often very perplexing to the young student. Then again I have not been able to trace the resting-place of the British type specimens of Haime Many of them were supplied to him from private cabinets, but I am unable to say whether the whole, or any part of them were placed in any English museum. In the second place, there was no pnblic collection of the Caen and Ranville fossils to refer to until recently. For some time past I have been collating a fine series of Caen Polyzoa for the purpose of description, which belongs to the Northampton Museum; and as much as possible I shall refer to these specimens in the course of my descriptions. Then there is a fine series of British examples in the cases of the School of Mines, and some in the British Museum. Recently, however, I have been, through the kindness of Dr. Pergens, supplied with a really good series of Mesozoic Polyzoa from various foreign horizons. and these bear the original names given to them by Lamouroux, Goldfuss, Michelin, D'Orbigny, 
Hagenow, and Haime, so that I shall have now-which I did not at one time have-available material for the purpose of instituting comparisons between the British and the Foreign species. After Haime Professor Brauns* able paper on Jurassic Bryozoa found in the neighbourhood of Metz, is a valuable addition to Jurassic Polyzoa literature. Then four papers by myself-1, Notes on the Family Diastoporidæ. Quart. Jour. Geol. Soc., Aug. 1881, pp 381390 ; 2, Brit. Assoc. Report on Fossil Polyzoa, Jurassic species, British Area only. Brit. Assoc. Rep., 1882-3. 3, Notes on Polyzoa found in the Boring at Richmond. Quar. Jour. Geol. Soc., Nov. 1884. 4, Jurassic Polyzoa in the neighbourhood of Northampton ; Journ. of the Northampton Nat. Hist. Soc., 1886. There is also a paper on Jurassic species, by F.D. Longe,F.G.S., on the Relation of the Escharoid Forms of Oolitic Polyzoa, \&c. Geo. Mag., 1881. Besides these there are scattered remarks in species found in papers by authors when describing Polyzoa from other horizons which will be referred to in passing

I have already indicated the leading ideas of Mr. A. W. Waters, in his several papers on Australian Tertiary Bryozoa ; and in my future studies of this interesting group of fossils, I shall note-if there be any to note--peculiarities of structure indicated, viz., the "closure," puncturing of the cells, growth, and arrangement of the cells in the colony.

I shall be glad of any help that can be given to me by collections in this labour of love; and I hope that much of the material that is hidden away in cabinets will be brought to light, and made available to the students of British Jurassic Polyzoa.

* Bryozeen des mittleren Jura der Gergend von Metz, in Zeitscher, D. Deutsch. Ges. Bd xxxi., 1879. 